\title{
A Managerial Coevolution Perspective in an Emerging Economy: Evidence From Turkey
}

\author{
XANTHIPPE ADAMOGLOU, YANNIS A. HAJIDIMITRIOU \\ Department of Business Administration \\ University of Macedonia \\ 156 Egnatia Street, 54636 Thessaloniki \\ GREECE
}

\begin{abstract}
The goal of this research is to conceptually unlink the relationship of MNEs, institutions and economic development, in order to shed light on how MNEs contribute to a country's institutional development and its economic development. To achieve this goal, this paper employs a coevolutionary approach, adopting and nurturing MNEs, institutions and economic development. The paper's goal is divided into two steps: The first step consists of the synthesis of the literature that is relevant with the coevolutionary approach, while the second involves the application of the synthesis to the emerging economy of Turkey for the period 1990-2011. Building on this foundation, the present exploratory paper's findings indicate the following: First, economic development is a function of a dynamic process which encapsulates all the regulative and normative aspects of an economy and the interaction of exogenous and endogenous forces. Second, the Turkish economy, during the 19902001 and the 2008-2011 periods experienced institutional avoidance. Furthermore, during 20022007 , the economy underwent a profound co-evolution process, which was accompanied with signs of institutional adaptation.
\end{abstract}

Key words: multinationals, FDI, coevolution, institutional adaptation, institutional avoidance, emerging economies, Turkey.

Received: November 7, 2019. Revised: May 12, 2020. Accepted: May 21, 2020. Published: May 29, 2020.

\section{Introduction}

Recently International Business (IB) scholars have investigated the relationship among Multinational Enterprises (MNEs), institutions and their importance for economic development [1] [2]. In this context, the theoretical inquiry posed above mainly revolved around the institutional reasoning under the lens of emerging economies [3-9]. The first reason that this takes place is because institutional theory provides an apposite conceptual setting, in which researchers and managers may decodify how institutions influence MNEs' activity in "mimetic isomorphism" terms [10]. The second reason is that emerging economies pose many questions concerning the sustainability of their economic development.

Although the studies cited above evangelised a new perspective of the manner that MNEs function, they mainly overlooked the ways in which a firm's active agency contributes to the shape and institutional change of the institutional framework [11-13] in the country in which they take place. This paper, recognising both the said literature gap and the callings of Lodge G., and Wilson C., and Kwok, C., and Tadesse, $\mathrm{S}$ [14, 15], considers the relationship between MNEs, institutions and economic development in emerging markets. Thus, it proceeds and conceptually frames the relationship of MNEs, institutions and economic development, employing the framework developed by Cantwell J., Dunning J., and Lundan M.S. [16] under the mosaic of the emerging economy of Turkey. This takes place in order to underline the functioning of three different forms of the co-evolutionary perspective, namely, institutional avoidance, institutional adaptation and institutional coevolution through the vulnerable and peculiar institutional framework of the Turkish economy.

In this perspective, this exploratory conceptual research makes the following unique contributions: i) it uses for the first time, to the best of our knowledge, a dynamic conceptual perspective of MNEs, institutions and economic development, ii) it underlies the peculiar institutional environment of the the Turkish economy to present the relationship of MNEs, institutions and economic development in 
a coevolutionary perspective, and iii) it recognises the necessity of reconciling the endogenous and exogenous forces of the integrative theoretical framework [16].

The rest of the paper is structured as follows: the next section clarifies and defines the notion of economic development, while it reviews the literature, associating evolutionary theory with MNEs, institutions and economic development. Then, a synthesis of the literature relevant with the framework developed by Cantwell J., Dunning J., and Lundan M.S. [16] is presented, followed by a discussion that analytically elaborates on the case of the Turkish economy. Next, the findings are presented and discussed. Then, the conclusions section focuses on the theoretical, managerial and policy implications of this research. In the final section the limitations and some suggestions for future research are presented.

\section{Literature Review and Theoretical Framework \\ 2.1 Literature Review and Definition of Economic Development}

This research, in order to address the relationship between MNEs, institutions and economic development, frames the conceptualisation of economic development. So, following North D.C. [17,18] and Dunning J., and Fortanier F. [19] New Development Path (NDP), Cantwell J., Dunning J., and Lundan M.S, [16], economic development is approached as the evolution of more complex institutions that deal with the uncertainties-imperfections arising from more complicated forms of exchange and involving both market and non-market actors [17,18].

In this setting, literature framed the interaction between MNEs, institutions and economic development both in an empirical and conceptual basis. More specifically, Dacin, M.T., Munir, K., and Tracey, P. [20] developed their arguments, within a conceptual framework, on the premises that institutions "serve both to powerfully drive change and to shape the nature of change across levels and contexts, but they also themselves change in character and potency over time" [20]. Furthermore, Acemoglu D., Johnson S., and Robinson J.A. [21] suggested that foreigners have a long history of affecting local institutions, while Dunning J., and Fortanier F. [19] shed light on the need that a New Development Path (NDP) should be developed in the International Business domain. In this setting, Dunning J., and Fortanier F. [19] tackle two main inquiries: first, to embrace the multidimensional aspect of economic development and, second, to create more opportunities for academics and policymakers to include various ways in which MNEs respond to the conceptualisation of economic development [19].

From their side, Carney M., and Gedajlovic E. [22] showed that the con-fluence between institutions and organisations facilitates the development of new organisational forms. Furthermore, Kostova T., Roth K., and Dacin M.T. [12] analyse the relationship between MNEs and institutions in two stages: first, they equate the MNEs' impact to that of institutions and, second, they re-establish the focus of International Business managers' attention to the critical issue that institutional differences do not work as disadvantages. Instead, subsidiaries' differences reflect a wide range of options for local actors through re-orienteering and re-establishing their approach of legitimacy based on the choice made by MNEs.

However, the most prominent research attempt is attributed to Cantwell J., Dunning J., and Lundan M.S. [16]. The argument this paper was based on is that MNEs function as agents that influence the institutional environment in which they operate. In this setting, it is argued that informal institutions produce more complex and unpredictable, "non ergodic" [16, 18] uncertainties-complexities "imperfections" [23] than formal institutions. MNEs are the solution to such uncertainties, since they "may [shape and] re-shape institutions, not only as constraints on particular courses of action, but also as resources of action that transform those institutions" [24].

In this light, MNEs' activity corresponds to the following three clusters of response/agency: a) Institutional avoidance, in which MNEs take the external institutional environment as exogenous, but in which MNEs are capable of making choices of de-localisation between different institutional environments, b) Institutional adaptation, in which MNEs also treat the institutional environment as exogenous, but they seek to adjust their own structures and policies to better fit in the host environment, and c) Institutional coevolution, in which MNEs treat the institutional environment to be partly endogenous by trying to both adapt to and affect change in local formal and informal institutions, although they may employ some of the same tactics as those employed under institutional adaptation [16]. 


\subsection{Theoretical Framework}

This paper, taking into account the literature reviewed above, while emphasising the Cantwell J., Dunning J., and Lundan M.S. [16] framework, it synthesises all the above, aiming to examine the relationship between MNEs, institutions and economic development, by studying the emerging economy of Turkey. In this direction, MNEs are considered to be one of the most prominent entities that may affect a country's strategy of development. They reflect institutional and organisational configuration settings [25] which are affected by their internal and external environment.

The perspective above, in conjunction with the coevolution process, indicates that coevolution takes part at both the macro- and the micro-levels of MNEs. Following this line of thought, and considering the case of institutional adaptation, studies have shown that economic, political and social institutions within a country can be favourable to certain firms' strategies and practices [26]. Subsequently, MNEs adapt to such institutional environments [27], according to the mimetic isomorphism argument [10].

Furthermore, considering the notion of selection or institutional avoidance, it is suggested that MNEs' micro- and macro-institutionalised frameworks interact with various and different institutional environments, which may create discrepancies-pressures under the conditions of subsidiaries' internal environments. This, however, produces discrepancies in the MNEs' internal environment, "which reduce internal legitimacy, integration, and stability of the organisation" [28]. Subsequently, MNEs may choose institutional avoidance, which could be expressed through opting for delocalisation. In this setting, Witt M.A., and Lewin A.Y. [29] argue that a slower pace of institutional change in some countries may be associated with higher rates of outward foreign direct investment (FDI), since MNEs want to depart from the institutional constraints of the host country [30], contributing, in this way, to lower levels of economic development in the host country.

Last, coevolution, following Cantwell J., Dunning J., and Lundan M.S. [16], is approached, herein, as a simultaneous and parallel process that reconciles two conceptualizations: MNEs agency and institutional adaptation. In this setting, when MNEs face peculiarities and voids in the host institutional environment in which they are going to develop their activities, they decide to 'intervene' implicitly by launching new organizational strategies which are applied in other similar cases. This stance, however, yields two main results: First, the motivation of the host agencies to cover uncertainties and peculiarities in order to attract MNEs in their country, and second, the motivation of local firms to adopt with incoming MNEs organizational policies, thereby producing positive spill-overs in the host country.

These arguments, combined also with the facts that a) MNEs' economic power, emanating from budgets that exceed by far those of several emerging countries [16], b) the institutional development of emerging economies tends to be superficial, and c) Turkey is affected by the Prime Minister's absolutism [31], lead this paper to the argument that the situation described above tends to burden MNEs with increased transaction costs. Therefore, in order to outrun the extra transaction costs emerging economies pose through their institutional peculiarities, MNEs tend to prefer to participate in the construction of new institutions through coevolution and put forward specific ideas that might make MNEs to be welcome in the host country $[16,32]$.

\section{The Case of Turkey}

This paper emphasises the emerging economy of Turkey as a useful institutional setting, in order to examine the notions of institutional avoidance, institutional adaptation and co-evolution theory. This choice is justified by the fact that, according to Yaprak A., Turkan Y., and Cetindamar D. [33], by the 2000s Turkey had become an economy mainly oriented towards industrial and international production. This situation contributed to a great extent to the fact that growing Turkish exports were directed to 160 countries, while high incoming FDI rates from countries from every continent [34] had been achieved. Furthermore, Turkey reflects an institutional fragmented economy that involves not only the setting up of new institutions, but also the significant increase in the powers of implementation $[35,36]$. For these reasons, Turkey provides an apposite research setting in which this paper may study conceptually the relationship between MNEs, institutions and economic development.

At this point it is important to emphasise that the conceptualisation of institutional adaptation, institutional avoidance and institutional coevolution, herein, will be captured by recognising both exogenous and endogenous [22] influences, as well as their interaction, so as to decodify and 
identify intertwined relationships. In addition, for methodological reasons, the period under study, i.e. 1990-2011, is divided into three main sub-periods, namely, 1990-2001, 2002-2007 and 2008-2011.

\subsection{The liberalisation phase (1990-2011) \\ 3.1.1 The phase of turbulence: 1990-2001}

Considering the said period, numerous critical events took place. In this direction, the official decision that the government took to liberalise the capital account was very important. This development led the Turkish economy to have been fully exposed to globalisation forces (technological advances, market diversification opportunities) (exogenous influences) and simultaneously to experience a "rhetorical transition" [36] phase or an institutional reconstruction.

In this framework, the Turkish political system experienced seven coalition governments (endogenous forces) which did not apply measures and practices that would have brought about tax compliance and economic growth [37]. These unstable political conditions, combined with the limited economic transformations, made Turkey face its first currency crisis in 1994 (endogenous forces). Turkey's imports were higher than its exports, producing current account deficits which were sustained for many years, changing actually the pattern of investments (hot money into IFDI) in the country [38]. Thus, it can be said that inward FDI (IFDI) and outward FDI (OFDI) stocks and flows have played a vital role in the country's economic performance and they should be watched and interpreted carefully over the years.

At the other end of the spectrum, the "implosion of the Soviet Union" [39] (exogenous forces), Turkey's Customs Union (endogenous forces) with the European Union (EU) in 1996 and the liberalisation of the former Soviet Republics (exogenous forces), brought about new economic opportunities, especially for the Turkish firms' internationalisation process [39]. However, the 1997 East Asian and the 1999 Russian currency crises (exogenous forces) overshadowed Turkish firms' internationalisation opportunities [40], since the crises brought about burdens both for MNEs and local firms, and also created the prerequisites for the economic crisis in 2001 (endogenous forces) [37]. As a corollary, capital inflows from abroad slowed down dramatically in the 1995-1997 period, leading Turkey to activate in December 1999 an IMF standby agreement (endogenous forces), which brought about a number of structural measures.
After 1996 Turkey's inward FDI performance presented an important improvement. In the same vein, internationalisation increased due to rising domestic market competition. In addition, Turkish firms turned to outsourcing, expanding their experience and increasing their sales. However, at the end of the 1990s, after the Turkish lira's 1994 re-overvaluation, market indicators dropped.

\subsubsection{The phase of economic and institutional development: 2001-2007}

During the period 2001-2007, and considering the many impediments it faced, the Turkish economy showed significant signs of a positive course that included important improvements both in the Turkish normative and regulative level. In this direction, the continuing process of liberalisation, the adoption of a new friendly foreign policy, which targeted at reducing international conflicts with neighbouring countries [39], and the implementation of the neoliberal model of New Public Management (NPM) norms and values [41], produced a virtuous cycle for the Turkish economy.

More specifically, in the early 2000s Turkey's political arena witnessed critical improvements, beginning with the ascent of the single-party rule after the 2002 elections (endogenous forces), which brought about political stability and attracted the attention of foreign investors. In monetary terms, many de jure incentive programs emerged [41]. These programs encouraged and facilitated the efforts of many local firms to expand internationally. However, they also damaged the free market mechanisms and created a basis for rent-seeking opportunism for specific local firms [39]. This was due to the long-standing overprotective policy pursued by the Turkish government towards foreign companies and specific local businesses, as well [39].

In addition, a new body, the Bank Regulatory and Supervisory Agency (BRSA) (endogenous forces), was established in 2000 [42]. Furthermore, serious official efforts took place during the period 2003-2010 in order to improve the investment climate, reducing institutional and bureaucratic impediments to investments through the enactment of Law No. 4875 in June 2003, which replaced Law No. 6224. This was a crucial step forward [35, 42] since, and according to OECD [43] statistics, IFDI reached \$745 million in 2003 and $\$ 8,427$ million in 2005 (endogenous factors) (see Table 1, at the end of the section). 
Additionally, Turkish enterprises overcame their competitiveness difficulties and expanded into Asian and European markets, "with government initiatives, favouring not only their outward expansion but also their partnerships with inward FDI investors as partners in the domestic market" [39]. Some examples that illustrate this turn are the companies Arcelik, Temsa, the Zorlu Group, Enka and Vestel, which gained significant market share and established their brands in the EU, the UK, Africa, Latin America and Asia [38]. These developments resulted in an exchange of norms, structures and knowledge between firms from developed EU and emerging economies and helped the former gain knowledge on how to expand in emerging economies and the latter to improve their organisational structures [33].

In accounts of IFDI, Turkey's popularity as an FDI destination is captured by the high amounts of IFDI in the period under study. In this perspective, Turkey's IFDI stock activity is described in Table 1 (presented in the Appendix) as follows: In 2003 it reached the amount of $\$ 33,239$ million, while in 2007 IFDI stock reached \$155,699 million, the highest level of all times. In 2003 the IFDI flow recorded the amount of $\$ 1,702$ million, while in 2007 it reached the amount of $\$ 22,047$ million. This is also illustrated by the country's share of developing countries' IFDI stock and flow amounts. More particularly, in 2003 its share of developing countries' IFDI stock corresponded to 1.8 percent and that of IFDI flow to 0.9 percent.

\subsubsection{The global crisis era: 2008-2011}

During this period, the critical aspect was the reverse course of the Turkish macroeconomic picture. This coincided also with the global economic crisis (exogenous forces) in 2008. In this ominous framework and at about 2010, negotiations between the EU and Turkey were interrupted, leading to "the suspension of eight ongoing chapters in 2006" [37] (exogenous forces), negatively influencing the institutional transformations in Turkey. This situation was exacerbated even more by Turkey's reluctance to implement human rights reforms, according to Copenhagen criteria (endogenous forces).

According to Table 1, what followed was that around 2007 IFDI investment decelerated (endogenous forces) and remained under the 2006 2007 level ever since, with the exception of two short-lived rebounds: one in 2008 when it reached $\$ 19,851$ million and the second in 2010 when it was
$\$ 9,086$ million. Furthermore, the most significant decline in IFDI flow during the period 2008-2011 was that from European countries [37, 44, 45].

\begin{tabular}{|c|c|c|c|c|c|c|c|c|c|}
\hline \multicolumn{10}{|c|}{ Table 1. Inward FDI Flows and Stocks in Millions of US Dollars } \\
\hline 2002 & 2003 & 2004 & 2005 & 2006 & 2007 & 2008 & 2009 & 2010 & 2011 \\
\hline \multicolumn{10}{|c|}{ Inward FDI Flows } \\
\hline 1,082 & 1,702 & 2,785 & 10,031 & 20,185 & 22,047 & 19,851 & 8,585 & 9,086 & 16,143 \\
\hline \multicolumn{10}{|c|}{ Inward FDI Stock } \\
\hline 18,826 & 33,239 & 38,617 & 71,416 & 95,516 & 155,699 & 81,338 & 144,820 & 188,447 & 138,053 \\
\hline
\end{tabular}

Source: Created by the Authors, 2020

\section{Findings and Discussion}

Considering a collective rather than an actorcentred analysis [46] presented in the previous sections, the present research reaches the following findings. Generally speaking, it is indicated that economic development is a multilevel, dynamic and historically-centred process which encapsulates both the conceptualisation of economic growth and institutional growth and the opposite. Considering the former, it is shown that MNEs' activity in many cases contributed positively to Turkey's institutional development. In this perspective, the presence of MNEs motivated Turkey's agencies to heal longterm institutional pathogens of the country. A characteristic paradigm was the application of the new FDI Law No. 4875 and the establishment of the BRSA in 2002 and 2000, respectively. This is based on the argument that many emerging economies realize that MNEs with well-coordinated structures are key factors, in order to face their own institutional inefficiencies and simultaneously create positive prerequisites for the attraction of other MNEs'. Considering the latter, and especially under the lens of the global crisis, it is shown that while an institutional downturn took place, an FDI downturn was occurred, as well.

Another important finding is that the notion of coevolution process that emerged in the specific contextual setting of Turkey was the outcome of the interaction of exogenous and endogenous forces that appear in the country. It is emphasised that different exogenous and endogenous conditions were being configured as either positive or negative conditions, which from their emergence either enhanced the economic and institutional development or understate their capability. Therefore, the interaction described in the previous section, sheds light on the fact that economic development may derive from sophisticated institutions, from underdeveloped institutions or from the interaction of both of them. More specifically, it is underlined that over the 
period 1990-2011 that is examined, the Turkish economy went through a coevolution process that involved both characteristics of institutional avoidance, institutional adaptation and institutional coevolution. In the turbulent 1990-2001 era and the 2008-2011 global crisis era the Turkish economy went through an institutional avoidance phase. During those two periods, adverse endogenous and exogenous factors led to an "institutional involution to International Business" (e.g., non-competitive environment) [31] or an institutional avoidance phase that resulted in the increase of investment outflows from the country. This development is explained by the decreased competitiveness of the Turkish economy, the lack of expectations for institutional changes in the country that pushed many MNEs to institutional avoidance, and the political and economic instability that further burdened competitiveness because high basic costs (energy, overheads and taxation) rendered operational costs even higher [47]. Furthermore, the appearance of institutional avoidance may be explained by the fact that while, initially the New Public Management rules tended to be a welcomed process in the Turkish economy, later on the established actors did not accept them. Consequently, this process yielded signs of strong influence of institutional inertia [48], since the embedded actors dominated over the agency of the rules of New Public Management.

Moreover, during the period 2002-2007, the Turkish economy underwent a profound coevolution process which was accompanied with signs of institutional adaptation. Coevolution emerged as the outcome of the interaction of both positive and negative endogenous and exogenous forces that appeared during that period. The incoming MNEs were experienced and, subsequently, adapted to a relatively liberalised economic and political environment, fostering in this way the demand for the development of better and more effective institutions in the Turkish economy. In addition, incoming MNEs facilitated the process of new business practices' spillovers. These aspects, combined with "persistent incentivization of both inward and outward FDI" [33] and the official encouragement to push for faster internationalisation processes and attraction of FDI, improved the "financial and market performance" [39] of the Turkish economy.

\begin{tabular}{|c|c|}
\hline $\begin{array}{c}\text { Table 2. Forms of MNEs' Institutional Engagement in the } \\
\text { Turkish Economy for the period 1990-2011 }\end{array}$ \\
\hline Period & Type of Coevolution \\
\hline $1990-2001$ & Institutional avoidance \\
\hline $2002-2007$ & $\begin{array}{c}\text { Coevolution with signs of institutional } \\
\text { adaptation }\end{array}$ \\
\hline $2008-2011$ & Institutional avoidance \\
\hline
\end{tabular}

Source: Created by the Authors, 2020

\section{Conclusions}

This paper presents, in a conceptual framework, how the institutional environment and the actions of MNEs interact and affect each other. Instead of focusing on temporary outcomes, this paper teased out the underlying processes of institutional change. The aim of the analysis is to achieve an exploratory understanding of the multiple relationships and feedback mechanisms that affect MNE evolution and induce changes in a country's institutional environment. To achieve this aim, a coevolutionary framework [16] was employed under the lens of a historical and contextual analysis of the endogenous and exogenous forces that appeared and interacted in Turkey during the period under study. In this analysis MNEs are approached as sub-institutions, which both co-evolved and interactively changed with other market and non-market institutions [25] in Turkey, while both institutional avoidance and adaptation were at play in the local economic environment. Therefore, the present MNE coevolution analysis has contributed to International Business research in the following ways: First, to the best of our knowledge, for the first time a dynamic perspective of MNEs, institutions and economic development has been employed, moving away from the static, mono-dimensional perspective of institutional reasoning. Second, the analysis highlighted the peculiar institutional environment of the Turkish economy, in an effort to present the relationship of MNEs with local institutions and economic development. Finally, this research recognised the necessity of reconciling the endogenous and exogenous forces prevailing in the Turkish economy during a well-defined time period, in order to achieve the expected dynamic perspective, as the framework by Cantwell J., Dunning J., and Lundan M.S. renders it necessary. Thus, it is believed that the present analysis provides a unique and holistic perception of the multiple relationships that affect MNEs' evolution and lead to changes in the host institutional 
environment [16].

Taking into account all the above, the paper at hand concludes that economic development is an evolving process that engulfs the conceptualisation of economic and institutional development and takes place through the interaction of both exogenous and endogenous forces. More specifically, economic development articulates a dynamic and incessant interaction that derives either from sophisticated institutions or from underdeveloped institutions or from the interaction of both of them and it is disguised under different forms of institutional change: institutional avoidance, institutional adaptation and institutional coevolution. Last, the analysis also concludes that the course of coevolution over time is far from certain. Therefore, this research strongly supports the idea that coevolution is neither a discrete event with a known outcome nor a steady march with a clear destination. It is an evolving and multidimensional process.

Furthermore, it is deduced that the Turkish economy, during the period studied, underwent all the aspects of a co-evolution process. During the 1990-2001 and 2008-2011 periods Turkey experienced institutional avoidance, encouraging mainly MNEs to depart form the idiosyncratic Turkish institutional framework. However, in the period 2002-2008, the Turkish government inaugurated a new phase for the political and economic arena of the country, since it implemented many critical positive institutional transformations that led to the genesis of a liberalised, business friendly and investment-oriented economy. Under these conditions, the fittest Turkish firms have had to shape up their organisational structures in order to be capable of recognising and responding to both domestic and international business challenges and opportunities. This process is mainly explained by the capabilities many Turkish firms developed during the 2002-2008 period [39].

\subsection{Managerial Implications}

As far as MNE managers are concerned, it is deduced that the said coevolution process may show a different approach of MNEs' activity that overcomes the deterministic, but still valuable aspect of institutional reasoning's mimetic isomorphism [10]. It reorients the locus of managers' attention to more elaborated and dynamic perspectives that encompass a number of critical determinants that define the notion of MNEs agency and, subsequently, MNEs' critical activity in the host countries where these activities take place.
In this context, this conceptual research analysis highlights the fact that MNEs are not passive entities that only react to each existing institutional framework in which they take place. Instead, it shows that MNEs are active entities that function as institutions [49], political entities [30] and modifiers of the host institutional environment. In this perspective, when certain MNEs perceive that they share the same objectives with other MNEs in the same field of the host country's environment, then they prefer to apply harmonised strategies in an attempt to act upon the environment [30]. This agency stance, however, it is not necessarily to be articulated by MNEs through a decisive purpose [50], but through MNEs' agent advantage to organise economic activity and induce changes to issues related to environment, society, education, poverty reduction and human rights.

\subsection{Policy Implications}

In policy terms, this research is timely from a public policy perspective and novel from a neoinstitutional perspective. The examination of a coevolution process under the prism of an emerging economy, even at this exploratory stage of study, is a hotly contested terrain all over the world [50]. Recent studies using neo-institutional theory have focused on the deregulation of industries and deinstitutionalization of regulatory logics [51]. In contrast, this research focuses on overlooked contests over the mix of formal and informal rules that may institutionalize certain logics and displace others. The present contextualized study demonstrates the causes of the conflicting voices that are heard as collective rationality with respect to a change in regulatory logics. In addition, this exploratory research on the application of a coevolutionary perspective in the emerging economy of Turkey offers a new awareness to policymakers. It casts some doubt on the effectiveness of host institutions and brings to the fore the effectiveness of MNEs agency, as well. Consequently, it is proposed that further research into the interaction between host institutions and MNEs agency would contribute to better-informed public policy that appreciates the positive transformational role of MNEs, as well as the vulnerabilities inherent in the development and enforcement of both public and private institutions [16]. 


\section{Limitations and Further Research}

The findings of our explanatory research study point to a number of limitations and guidelines for future research. The first limitation consists of the absence of an empirical analysis which would be based either on a vigorous qualitative or a rigorous longitudinal study that would build dynamic richness in the understanding of the coevolution process in an emerging economy. The second limitation is the lack of the inclusion of other nonmarket players, beyond MNEs, such as small and medium firms, which would broaden the conceptualisation of the coevolution process in an emerging country as well. Finally, it is recognised that the potential for the generalisation of this study's conclusions is limited, since such exploratory research must also be applied to other transition and/or emerging economies, or even to industry specific county settings, which, in turn, will enhance the validity of the conclusions obtained in this research.

Based on the limitations presented, future studies have the opportunity to consider numerous research directions. Initially, it is proposed that an econometric research effort into the kinds of questions that have been posed herein will contribute "to better-informed public policy that appreciates the positive transformational role of MNEs, as well as the vulnerabilities inherent in the development and enforcement of both public and private institutions" [16].

Furthermore, and considering the fact that the Turkish economy still faces key structural and institutional issues related to its recent political and economic activity, it is suggested that an extension of the time period under study would be useful in order to capture contemporary endogenous and exogenous forces that affect the coevolutionary process of the idiosyncratic Turkish institutional setting. In addition, and following the paradigm of Cantwell J., Dunning J., and Lundan M.S. (2010) [16], it is suggested that the coevolution process analysed before, that is, institutional avoidance, institutional adaption and institutional coevolution, would be enhanced by the employment of a historically-centred reasoning, such as appreciative theory [52]. A complimentary conceptual reasoning that would broaden, establish and shed light on a strong relationship between coevolution process and economic development, could be offered by the appreciative theory.

Finally, it is suggested that the research analysis of the coevolution process presented above may be implemented also in specific and critical aspects of MNEs' activity, for example the entry mode strategies utilised by MNEs. The said 'transfusion', that is, the coevolution into the entry mode domain, would open up new and innovative conceptual, empirical and practical paths, both for International Business researchers and managers. More specifically, it is suggested that the inclusion of a coevolution process in the entry strategy domain, it would provide researchers and managers with the capability to overcome the notion of embedded practices, creating in this way prerequisites for the development of a new entry mode co-evolution process. According to Benito G.R.G., Welch L., and Petersen B. [53], such a coevolution process is already sending out signs of entry mode adaptation, entry mode avoidance and entry mode dynamics.

\section{References}

[1] Barro, R. Democracy and Growth, Journal of Economic Growth, 1996, Volume 1 No. 1:127.

[2] Kedia, B., Clampit, J., and Gaffney, N. The role of institutions and multinational enterprises in economic development, in Wood, G., and Demirbag M., (Eds), Handbook of Institutional Approaches to Internationa $l$ Business: Cheltenham, UK, and Northampton, USA: Edward Elgar, 2012:236-273.

[3] Doh, J., Howton, S.D., and Howton, S.W. Does the market respond to institutional endorsement of social responsibility? The role of information, institutions and legitimacy, Journal of Management, 2010, Volume 36 No. 6:1461-1485.

[4] Globerman, S., and Shapiro, D. Global foreign direct flows: the role of governance infrastructure, World Development, 2002, Volume 30 No 11: 1898-1819.

[5] Haber, S., North, D., and Weingast, B. If economists are so smart, why is Africa so poor?', 2003, Wall Street Journal, 30 July.

[6] Hall, P.A., and Soskie, D. An Introduction to Varieties of Capitalism, New York: Oxford University Press, 2001.

[7] Jackson, G., and Deeg, R. Comparing Capitalisms: Understanding Institutional Diversity and its Implications for International Business, Journal of International Business Studies, 2008, Volume 39 No. 4: 540-561.

[8] Scott, W.R. Institutions and organizations, 
Thousand Oaks: Sage, 1995.

[9] Whitley, R. Divergent Capitalisms: The Social Structuring and Change of Business System s, New York: Oxford University Press, 1992.

[10] DiMaggio, P.J., and Powell, W.W. The Iron Cage Revisited: Institutional Isomorphism and Collective Rationality in Organizational Fields, American Sociological Review, Volume 48, 1983, No. 2: 147-160.

[11] Carney, M., Gedajlovic, E., and Yang, X. Varieties of Asian capitalism: Toward an institutional theory of Asian enterprise, Asia Pacific Journal of Management, 2009, Volume 29 No. 3: 361-380.

[12] Kostova, T., Roth, K., and Dacin, M.T. Institutional Theory in the Study of Multinational Corporations: A Critique and New Directions, The Academy of Management Review, Volume 33 No. 4, 2008: 994-1006.

[13] Saka-Helmhout, A., and Geppert, M. Different Forms of Agency and Institutional Influences within Multinational Enterprises, Management International Review, 2011, Volume 51 No. 5: pp. 567-592.

[14] Lodge, G., and Wilson, C. Multinational corporations and global poverty reduction, Challenge, 2006, Volume 49 No. 3: 17-25.

[15] Kwok, C., and Tadesse, S. The MNC as an agent of change for host-country institutions: FDI and corruption, Journal of International Business Studies, 2006, Volume 37: 767-785.

[16] Cantwell, J., Dunning, J., and Lundan, M.S. An evolutionary approach to understanding international business activity: The $\mathrm{co}^{-}$ evolution of MNEs and the institutional environment, Journal of International Business Studies, 2010, Volume 41: 567-586.

[17] North, D.C. Institutions, institutional change and economic performance, Cambridge: Cambridge University Press, 1990.

[18] North, D.C. Understanding the process of economic change, Princeton, NJ: Princeton University Press, 2005.

[19] Dunning, J.H., and Fortanier, F. Multinational enterprises and the new development paradigm: consequences for host country development, Multinational Business Review, 2007, Volume 15 No. 1: 25-46.

[20] Dacin, M.T., Munir, K., and Tracey, P. Formal dining at Cambridge colleges: linking ritual performance and institutional maintenance, Academy of $M$ anagement Journal, 2010, Volume 53 No. 6: 1393-1418.
[21] Acemoglu, D., Johnson, S., and Robinson, J.A. The Colonial Origins of Comparative Development: An Empirical Investigation, The American Economic Review, 2001, Volume 91 No. 5: 1369-1401.

[22] Carney, M., and Gedajlovic, E. The Rise of Family Business Groups in the ASEAN Region, Journal of Management Studies, 2002, Volume 39 No 1: 123-146.

[23] Lundan, S. The Coevolution of Transnational Corporations and Institutions, Indiana Journal of Global and Legal Studies, 2011, Volume 18 No. 2: 639-663.

[24] Deeg, R., and Jackson, G. Towards a more dynamic theory of capitalist variety, SocioEconomic Review, 2007, Volume 5:149-179.

[25] Madhok, A., and Liu, C. A coevolutionary theory of the multinational firm, Journal of International Management, 2006, Volume 12: $1-21$.

[26] Meyer, K.E., and Nguyen, H.V. Foreign investment strategies and sub-national institutions in emerging markets: Evidence from Vietnam, Journal of Management Studies, 2005, Volume 42 No. 1: 63-93.

[27] Chan, C.M., Isobe, T., and Makino, S. Which country matters? Institutional development and foreign affiliate performance, Strategic Management Journal, 2008, Volume 29,: 1179-1205.

[28] Uhlenbruck, K., Rodriguez, P., Doh, J., and Eden, L. The Impact of Corruption on Entry Strategy: Evidence from Telecommunication Projects in Emerging Economies, Organization Science, 2006, Volume 17: 402-414.

[29] Witt, M.A., and Lewin, A.Y. Outward foreign direct investments as escape response to home country institutional constraints, Journal of International Business Studies, 2007, Volume 38 No. 4: 579-594.

[30] García-Cabrera, A., and Durán-Herrera, J.J. MNEs as institutional entrepreneurs: a dynamic model of co-evolution process, European Management Journal, 2016, Volume 12 No 3: $1-14$.

[31] Durán-Herrera, J.J., and García-Cabrera, A. Crisis and MNEs as Institutional Entrepreneurs: An Analysis from a Co-evolutionary Perspective, 2013, (http://www3.eeg.uminho.pt/economia/nipe/iib c2013/4.1.pdf. Accessed June 2019).

[32] Hoskisson, R.E., Eden, L., Lau, C.M., and Wright, M. Strategy in emerging economies, 
Academy of $M$ anagement Journal, 2002, Volume 43 No. 3: 249-267.

[33] Yaprak, A., Turkan, Y., and Cetindamar, D. The influence of firm-specific and countryspecific advantages in the internationalization of emerging market firms: Evidence from Turkey, International Business Review, 2017, Volume 27 No. 1: 198-207.

[34] Merger and Acquisitions Report Turkey. 2018. (https://www2.deloitte.com/content/dam/Deloit te/tr/Documents/mergers-acqisitions/annualturkish-manda-review-january-2017.pdf.

[35] Adamoglou, X., and Kyrkilis, D. FDI Entry strategies as a function of distance - The Case of an Emerging Market: Turkey, Journal of the Knowledge Economy, 2016, Volume 9 No. 4: 1348-1373.

[36] Önis, Z., and Bakır, C. Turkey's political economy in the age of financial globalization: the significance of the EU anchor, South European Society and Politics, 2007, Volume 2: 147-164.

[37] Acemoglu, D., and Ucer, M. The Ups and Downs of Turkish Growth, 2002-2015: Political Dynamics, the European Union and the Institutional Slide, 2015, NBER Working Paper No. 21608 Issued in October 2015.

[38] Ayden, Y., Demirbag, M., and Tatoglu, E. Internationalization of the Turkish Business Environment: Historical Evolution and New Realities, In Ayden, et al (Eds), Turkish Multinationals Market Entry and PostAcquisition Strategy, Palgrave Studies of Internationalization in Emerging Markets, 2018:11-33.

[39] Karademir, B., and Yaprak, A. The coevolution of the institutional environments and internationalization experiences of Turkish internationalising firms', in Wood, G., and Demirbag, M., (Eds), Handbook of Institutional Approaches to Inte rnational Business, Cheltenham, UK, and Northampton, USA: Edward Elgar, 2012: 236-270.

[40] Yavaci, A., and Dogan, S. Geopolitics, geoculture and Turkish foreign policy. Academia edu, 2012, https://www.academia.edu/2565092/Geopolitic s Geoculture and Turkish Foreign Policy

[41].Atiyas, I. Economic Institutions and Institutional Change in Turkey during the Neoliberal Era, New Perspectives on Turkey, 2012, Volume 14: 45-69.
[42] Çanaçki, İ.H. Business environment in Turkey paper, Paper presented to Knowledge Economy Forum IV, 2005, Istanbul, 22 March.

[43] OECD. OECD science, technology and industry outlook. OECD Publishing 2018 [available at http://10.1787/sti_outlook-2010 en (Accessed 31 January 2019)].

[44] Isiksal, A.Z., Isiksal, H., and Jalali, H. The Impact of Foreign Direct Investment in Turkey 2010-2016, Economics, 2017, Volume 5 No. 2: $69-81$.

[45] UNCTAD. World Investment Report 2018: Foreign Direct Investment and the Challenge of Development. Geneva: UNCTAD, 2018.

[46] Hardy, C., and Maguire, S. Institutional entrepreneurship. In: Greenwood, R., Suddaby, R., Sahlin, K. (Eds.), The SAGE Handbook of Organizational Institutionalism. Sage Publishing, Los Angeles, 2008:198-217.

[47] Eren-Erdogmus, I., Cobanoglu, E., Yalcin, M., and Ghauri, P.N. Internationalization of emerging market firms: the case of Turkish retailers. International Marketing Review, 2010, Volume 27 No. 3: 316-337.

[48] Battilana, J., Leca, B., and Boxenbaum, E. How actors change institutions: towards a theory of institutional entrepreneurship, The Academy of Management Annals, 2009, Volume 3 No. 1: 65-77.

[49] Yiu, D., and Makino, S. The choice between joint venture and Wholly Owned Subsidiary: an institutional perspective', Organization Science, 2002, Volume 13 No. 6: 667-683.

[50] Khavul, S., Chavez, S., and Bruton, G.D. When institutional change outruns the change agent: the contested terrain of entrepreneurial microfinance for those in poverty, Journal of Business Venturing, 2013, Volume 18 No. 13: 30-50.

[51] Lounsbury, M. Institutional transformation and status mobility: the professionalization of the field of finance, Academy of $M$ anagement Journal, 2002, Volume 45 No. 1:255-266.

[52] Nelson, R.R., and Winter, S.G. An evolutionary theory of economic chan ge, Cambridge, MA: Harvard University Press, 1982.

[53] Benito, G. R. G., Welch, L and Petersen, B. Towards more realistic conceptualisations of foreign operation modes. Journal of International Business Studies, 2009, Volume $40 \quad$ No. $\quad 9$ : 1455-1470. 